\title{
Accountability from the Perspective of the Forum: \\ Citizens' Attitudes towards Accountability in Europe
}

\section{Keywords:}

Accountability; public opinion; European Social Survey; welfare states; media; government performance; rule of law; ideology.

\section{Correspondence Address:}

Ixchel Pérez Durán, Institut Barcelona d'Estudis Internacionals (IBEI), Carrer de Ramon Trias Fargas, 25, 08005 Barcelona, Spain. email: iperez@,ibei.org.

\section{Notes on Contributor:}

Ixchel Pérez Durán is Postdoctoral Research Fellow at Institut Barcelona d'Estudis Internacionals (IBEI). Her research focuses on accountability for public policies, accountability in European welfare states, European Parliament oversight, and interest group influence in European Union agencies. [iperez@ibei.org]

\section{Acknowledgements:}

I am grateful to the two anonymous referees for their helpful and constructive comments. I also thank to Guillermo Landrove, Jorge Rodríguez and Marc Van de Wardt for their valuable comments and suggestions. Previous versions of this article were presented at the 2014 ECPR Joint Sessions of Workshops in Salamanca, and at the 2014 NewGen Accountability Workshop organised by the Utrecht School of Governance. I would like to thank all participants for their valuable discussion on previous version of this article.

\section{Disclosure Statement:}

No potential conflict of interest was reported by the author. 


\begin{abstract}
The aim of this article is to analyse citizens' attitudes towards government accountability in 24 European countries and to examine the influence of contextual and individual factors on perceptions of accountability. Using as a dataset the European Social Survey (ESS, 2012), the results show that citizens respond positively when the media provides reliable information on which to judge the government, when individuals perceive that governments perform well, when individuals live in more extensive and generous welfare states and when they live in countries where the rule of law is firmly established. In addition, the findings also provide evidence that compared to politically left-wing citizens, right-wing supporters have, on average, a higher perception of government accountability. In particular, the findings show strong positive evaluations of right-wing governments by right-wing voters in comparison with leftwing governments by left-wing voters.
\end{abstract}

\title{
Introduction
}

From the traditional definition of accountability as a relationship between an actor and a forum (Bovens 2007, 2010), most research on accountability has focused on the analysis of the mechanisms carried out by the actor (the responsible actors for accountgiving). In particular, accountability has been studied more as a hierarchical control mechanism between different administrative levels than as a social relation between citizens and their governments (Brandsma and Schillemans 2013, Page 2010). This article, by contrast, focuses on the broadest forum for holding governments to account: their citizens. Specifically, the aim of this paper is to analyse people's attitudes regarding government accountability in 24 European countries and to examine to what extent contextual and individual factors influence citizens' perceptions of accountability.

In the existing literature on governmental accountability, some studies have centred on conceptualising accountability (e.g., Bovens 2007, 2010, Hood 2010, Lindberg 2013, Mulgan 2000, Olsen 2013, Papadopoulos 2010, Philp 2009) while other studies have developed advances in measurement of de jure and de facto accountability mechanisms (e.g., Biela and Papadopoulos 2014, Busuioc 2013, Koop 2011, 2014). Less commonly, 
some scholars have also begun to investigate the explanatory variables of accountability, focusing especially on analysing political and institutional factors. For example, in a study on national regulatory agencies, Hanretty and Koop (2013) suggest that the rule of law is relevant for explaining differences in levels of formal and actual accountability. In addition, some studies have found that under coalition governments, as opposed to single-party governments, citizens have a weaker capacity to sanction governments during elections since the attribution of responsibility is blurred within multi-party governments (e.g. Powell and Whitten 1993, Vowles 2010) and that, further, multiple levels of decision-making blur governmental responsibility (e.g. Fisher and Hobolt 2010, León 2011, Wlezien and Soroka 2012). However, relatively little is known about the possible effect of contextual and individual factors on citizen perception of governmental accountability.

The present research seeks to contribute to the literature on accountability by, firstly, assessing it through the perceptions of citizens, who in representative democracies are the primary recipients of accountability. Assessing accountability from the perception of citizens would serve as a 'thermostat function' (Koster and Kaminska 2012) that would provide an understanding of the reach of accountability mechanisms implemented by governments. In addition, this research seeks to contribute to the scholarship on accountability by examining the influence of governmental characteristics and the characteristics of citizens. Using the data of the European Social Survey (ESS, 2012), the paper assesses to what extent citizens perceive their governments as accountable. At the individual level I examine variables that previous studies on institutional trust have found to be relevant: citizens' ideological position, ideological proximity to the ruling party and satisfaction with government performance (Devos et al 2002, Muñoz et al 2011). In addition, I also investigate another factor that has received less attention: people's perceptions of the information provided by the media (Schillemans 2012). At the country level I analyse the effect of the rule of law, governance structures and a further variable that has received little attention in studies on accountability: the type of welfare state adopted by countries.

The results provide evidence that citizens are more likely to perceive their governments as accountable when individuals perceive that governments perform well, when the media provides them with reliable information on which to judge the government, when they live in countries where rule of law is well established, and in countries where the welfare state is more generous and has a higher degree of decommodification. The findings also provide evidence that compared to politically left-wing citizens, right- 
wing supporters have, on average, a higher perception of government accountability. Furthermore, the results also show that the closer respondents are to the ruling party ideologically, the more inclined they will be to find the government accountable. In particular, the findings show strong positive evaluations of right-wing governments by right-wing voters in comparison with left-wing governments by left-wing voters.

The article is structured as follows. The next section conducts a theoretical discussion of accountability. Then, the assessment of the level of accountability as perceived by citizens is presented. Next, the paper discusses the scholarly literature on the variables that may be relevant for explaining perceptions of accountability, as well as the hypotheses that may be derived from this literature. This is followed by an operationalisation of the independent variables and an analysis of the results from the statistical analysis conducted on those variables. Finally, some conclusions are drawn.

\section{Accountability from the perspective of the forum: Citizens' control of government}

According to the existing literature, accountability involves the capacity of accountgiving and holding-to-account between at least two parties. In general terms, it implies the following elements: i) one or more actor(s), A, who has/have the obligation to be accountable to another/other actor(s), B; ii) an issue about which to be accountable (M); and, iii) one or more actor(s), B, the recipient(s) of such accountability, who has/have the right to ask $\mathrm{A}$ for information and justification about its/their decisions and actions, as well as the right to sanction them (Bovens 2007, Dubnick and Frederikson 2009, Grant and Keohane 2005, Lindberg 2013). From this definition, two phases of accountability can be distinguished: one phase where actor(s) A provide(s) information and justification to actor(s) B about its/their actions, performance, and/or results obtained in matters of the issue it/they has/have been delegated (the informative/ justifying dimension); and a second phase, where actor(s) B can evaluate and sanction such actions and performance carried out by actor A(s) (the evaluative/sanctioning dimension).

Based on principal-agent theory, it has been argued that accountability derives from an act of delegation of authority from a principal to an agent, which entails a discretional area that leads to the need to control that agent (Lindberg 2013, Strøm 2000). Although accountability can be associated with different forms of regimes (Gregory 2003, Philp 2009, Romzek and Dubnick 1998), it can be applied to representative democracies because such a political system implies an act of delegation by citizens to a government 
that should act in representation of their interests (Przeworski et al 1999). Those citizens should, in turn, have mechanisms to control and sanction that government. That is to say, rulers - both elected and non-elected - who 'make decisions on behalf of a political community' have an obligation to respond to citizens (Olsen 2013: 447). Hence, although there are possible tensions between accountability and representation, they nonetheless 'require one another in modern democracy' (Lord and Pollak 2010). In fact, the classic distinction between horizontal and vertical accountability also reminds us that accountability has a strong relationship with citizens as a relevant forum. While horizontal accountability is carried out by different state agencies (such as audit offices, ombudsmen and courts that are legally empowered to call into question those state agencies (O’Donnell 1998: 117), vertical accountability is carried out in hierarchical relationships; in 'upward' processes (Hood 2010), for example, where a parliament asks a minister for accountability (Schillemans 2008), or else in 'downward' processes (Hood 2010), particularly in relationships derived from an act of authority between citizens who ask for accountability from their governments.

\section{Assessment of government accountability from the perspective of the citizens' forum}

How can public accountability be assessed from the perspective of citizens? In a current study on satisfaction with democracy in Russia and the United Kingdom, Moncagatta (2012) suggests using different indicators included in the ESS for assessing citizens' evaluations of the functioning of their democracies. Particularly, Moncagatta (2012) uses the question 'To what extent do you think the government in your country explains its decisions to voters?' as an indicator of vertical accountability (one of the items the author uses to assess support for democracy). In this study I assess government accountability from the perception that citizens have of the functioning of two central dimensions of accountability: the informative/justifying dimension and the evaluative/ sanctioning dimension (Pérez Durán, 2015). That is to say, I assess accountability from the perception of citizens regarding the information and justification they receive from their governments, as well as about the functioning of different mechanisms to evaluate and sanction such governments.

Specifically, in order to measure citizens' attitudes towards accountability I use the module on democracy of the ESS (6th round 2012) because it provides data about citizens' perception regarding the elements that make up the two dimensions of accountability: whether the government informs about and justifies its decisions and 
actions, and whether there are mechanisms for evaluating and sanctioning that government. I cannot include previous ESS waves in the analysis since these lack the relevant questions to measure our dependent variable.

In line with Moncagatta (2012), I focus on the following question to measure the informative/justifying dimension: 'To what extent do you think the government in your country explains its decisions to voters?' on a scale from 0 (Does not apply at all) to 10 (Applies completely). This question serves as an indicator of the reach that the information and justifications that citizens receive from their governments have. To measure the evaluative/sanctioning dimension I focus on the following question: 'Are governing parties in your country punished in the elections when they have done a bad job?' on a scale from 0 (Does not apply at all) to 10 (Applies completely). This question assesses whether elections 'are truly an instrument' for evaluating and sanctioning 'with which voters can punish or reward incumbents' (O’Donnell, 1998: 2).

I created a summary index that averages the two responses on a scale from 0 to 10 . To test reliability between the two indicators of accountability used I computed Cronbach's alpha statistic. These two items have a scale reliability coefficient alpha of 0.69 . To confirm whether the two indicators of accountability measure the same concept I also use Mokken scale analysis. As can be seen in Table 1, the Loevinger coefficients of homogeneity for both items are above 0.50, showing that both items are strongly correlated.

[Table 1 Mokken scale analysis for accountability items]

\begin{tabular}{|l|c|c|c|}
\hline Item & $\mathrm{N}$ & Loevinger's $\mathrm{H}$ & $\mathrm{p}$-value \\
\hline Informative/justifying dimension & 41,933 & 0.53861 & 0.00000 \\
\hline Evaluative/sanctioning dimension & 41,933 & 0.53861 & 0.00000 \\
\hline
\end{tabular}

In order to show the differences found in citizens' perception on accountability, Table 2 shows the index obtained in the countries analysed. As can be observed, the countries that obtain the highest index are primarily the Scandinavian countries, Switzerland and the Netherlands. A second group is formed by Germany, Ireland, the United Kingdom, Iceland, Belgium and France, and a third group is made up of the formerly Communist 
countries of Central and Eastern Europe (e.g. Czech Republic, Slovakia and Slovenia) along with Mediterranean countries (e.g. Italy and Spain).

[Table 2. Index of citizens' attitudes on government accountability per country]

\begin{tabular}{lcc} 
Country & $\begin{array}{c}\text { Accountability } \\
\text { Index }\end{array}$ \\
Sweden & 7.13 \\
Denmark & 7.11 \\
Switzerland & 7.01 \\
Norway & 6.93 \\
Finland & 6.88 \\
Netherlands & 6.33 \\
Ireland & 6.07 \\
United & 5.80 \\
Kingdom & 5.68 \\
Belgium & 5.36 \\
Germany & 5.42 \\
France & 5.17 \\
Slovakia & 5.12 \\
Iceland & 4.82 \\
Slovenia & 4.62 \\
Poland & 4.47 \\
Hungary & 4.35 \\
Spain & 4.33 \\
Bulgaria & 4.17 \\
Cyprus & 4.18 \\
Lithuania & \\
Portugal & \\
Estonia & Czech Republic & \\
Italy & 3.05 \\
\hline
\end{tabular}


Drawing on institutional theory that argues that institutions provide stability as well as the rules that guide or constrain individual actions (North 1990), some scholars have emphasised that citizens' attitudes are embedded and shaped by institutional variables (Anderson and Singer 2008). As noted, from current scholarship on accountability we know: firstly, that in the case of regulatory agencies the rule of law and the presence of veto players in a polity are relevant variables to explain differences in levels accountability (Hanretty and Koop 2013); secondly, that under coalition governments, as opposed to single-party governments (Fisher and Hobolt 2010), citizens have a weaker capacity to sanction governments during elections since the attribution of responsibility is blurred within multi-party cabinets/governments (Powell and Whitten 1993, Vowles 2010); and, thirdly, that multiple levels of decision-making - such as multiple levels of administrative and political decentralisation - cloud the responsibility of governments (Fisher and Hobolt 2010, León 2011). In addition, extant research on political trust has also demonstrated that individual characteristics of citizens also matter in explaining their perceptions. For example, Muñoz et al (2011) found that trust in national institutions and satisfaction with public services are closely related to trust in European Union institutions.

Since it is reasonable to expect that contextual and individual factors affect citizens' perceptions, the present research addresses a combination of these to explain attitudes towards government accountability. At the contextual-level I analyse the effect of the rule of law and governance structures - particularly the presence of multiparty governments and strong regional governments. I also analyse a variable that has been largely ignored in studies on accountability: the type of welfare state adopted by countries. At the individual-level, I examine three variables that previous studies have found to be relevant with regard to trust in political institution - ideological position, ideological proximity, and satisfaction with government performance (Devos et al 2002; Muñoz et al 2011) - as well as a variable that has yet to be addressed; the influence of information provided by the media to citizens.

It is important to note that although some of the variables have already been analysed in the literature on institutional trust, the concepts of trust and accountability should not be taken to be synonymous. While trust in institutions 'can be considered as a blanket judgement, covering the functioning of the political system in general' or as the 'diffuse support for the fundamental values and institutions of a political system' that 'is not related to the attitude on or the evaluation of current office-holders' (Hooghe and Kern 2013: 2), attitudes towards accountability refer to citizens' perceptions of the 
mechanisms that governments have in place to inform and justify their decisions and actions, as well as to the available mechanisms to evaluate and sanction such actions.

\section{Government performance}

Scholarship on the quality of government (Dahlberg and Holmberg 2013) and on trust in political institutions (Muñoz et al 2011) has delved into the factors that influence government performance. In line with such studies this article seeks to analyse whether perceptions of government performance are associated with citizens' perceptions of government accountability. Research on economic voting has demonstrated that perceptions of economic performance (as a measure of government performance) affect support for the government (Anderson 1998) on the basis that performance matters because citizens 'tend to reward or punish the incumbent party for economic conditions' (Kayser and Wlezien 2011). Another way to examine government performance is through attitudes toward public services. For instance, Kumlin (2009) finds that dissatisfaction with national public services - especially with welfare state services has a direct (negative) effect on trust in both national governments and EU institutions. Research on trust, particularly the work of Muñoz et al (2011), also confirms that satisfaction with welfare public services seems to foster trust in European institutions. Building on these contributions, one might expect that the citizens who evaluate government performance favourably would tend to support the accountability mechanisms carried out by such a government. This argument leads to the following hypothesis:

Hypothesis 1. The higher individuals' satisfaction with government performance, the higher their perception of government accountability.

\section{Ideological position of citizens}

From scholarship on political attitudes we know that ideology affects levels of citizens' trust and support for different political institutions. For example, Anderson and Singer (2008) found that the negative effect of income inequality on attitudes about public institutions is higher among individuals who placed themselves on the political left, since citizens on the left of the political spectrum are more sensitive to social inequalities than citizens located on the right. Furthermore, some studies have found that individuals on the right of the political spectrum express more positive evaluations of political institutions than those on the left (Devos et al 2012). The core argument 
developed by Devos et al is based on the idea that right-wing supporters display a relatively high level of "conservation values" - that is, a desire to preserve the status $q u o$ - whereas left-wing supporters have a high degree of "openness to change higher order values" as well as greater scepticism towards institutions (2012: 484). On this basis, if it is assumed that individuals on the right express more positive perceptions of political and public institutions, one might also expect that such individuals would have more favourable perceptions of government accountability. Moreover, since current research has emphasised that 'many people in society consider themselves as centrist' (Rodon 2014: 3), this research also seeks to empirically test whether the centre or 'neutral position' in the ideological scale affects individual attitudes towards accountability. In particular, it could be expected that if individuals identify themselves as ideologically neutral or moderate then, similarly, neither their expectations nor their assessments of accountability would be extreme.

Hypothesis 2. Individuals with a left-wing position on the political spectrum have lower perceptions of government accountability, while individuals with centre and right-wing positions express a more positive evaluation.

\section{Ideological proximity with the ruling party}

The previous hypothesis $(\mathrm{H} 2)$ points to the potential importance of the ideological position of citizens. In addition, the evidence of current studies (see De Vries and Tillman 2011) suggests the need to examine whether citizens' ideology matters while also taking into account their ideological proximity to the ruling party; that is to say, to analyse whether citizens are more inclined to perceive the government as accountable when they feel ideologically close to the ruling party. In particular, one would expect that greater agreement between the ideology of the respondent and the ruling party would increase the respondent's positive evaluation of government accountability.

Hypothesis 3. Individuals with greater ideological proximity to the ruling party have higher perceptions of government accountability.

\section{Media}

Recent empirical studies confirm that political information provided by independent media, understood as the 'watchdog of democracy', 'helps citizens to evaluate the performance of their elected leaders, both individually and collectively' (Norris 2014: 
526). Since citizens are subject to information asymmetries regarding government information (Maggetti 2012), the media can play an important role in accountability because it enables citizens to effectively monitor the government's actions. More specifically, some studies have demonstrated that 'richer informational environments' allow citizens to become 'more knowledgeable' about government decisions (Arnold 2004: 247). In this vein, Schillemans and Jacobs (2014) suggest that the media may trigger accountability by publishing information that is used by some actors to call an organisation to account. Based on this idea, I suggest the following hypothesis:

Hypothesis 4. Individuals who consider the media to provide citizens with reliable information to judge the government express a more positive assessment of government accountability.

Rule of law

The concept of the rule of law has been studied from the perspective of various political and legal theories. Rodríguez et al (2010) have argued that 'where the rule of law is absent, we cannot govern the governors, and thus we are subject to official prerogative, which may be arbitrary, capricious, and brutal' (2010: 1457). This article seeks to analyse the effect of the rule of law on citizens' perceptions of accountability because the effectiveness of rule of law could reflect the extent to which accountability structures are actually present (e.g. checks and balances between different branches of the state) (Hanretty and Koop 2013). Thus, one might expect that citizens' perceptions of accountability are stronger in countries where the rule of law is well established.

Hypothesis 5. The greater the establishment of the rule of law, the more positive are citizens' perceptions on accountability.

\section{Governance structures}

Some scholars have found that electoral accountability is weaker for coalition governments than for single-party governments (Fisher and Hobolt 2010) because under coalition governments citizens cannot clearly discern who is responsible for past performance (Powell and Whitten 1993). In a similar argument Vowles (2010) has suggested that, compared to single-party governments, citizens have a weaker capacity to sanction coalition governments in elections because the attribution of responsibility is 
blurred within multi-party cabinets/governments. Hence, I put forward the following hypothesis:

Hypothesis 6a. The perception of government accountability by citizens is higher in states governed by single party governments than in those governed by coalition governments.

In a similar vein, some scholars have argued that multiple levels of decision-making cloud governmental responsibility (Chaqués and Palau 2011, Fisher and Hobolt 2010, León 2011, Wlezien and Soroka 2012). One characteristic that could be used to analyse governmental structure is the distinction between federal and unitary countries. However, from this general distinction, countries such as Spain or the United Kingdom would be classified as unitary when, in reality, their regional governments possess powers that make them more like a quasi-federal system. Consequently, in order to examine whether governmental structure is a relevant determinant of perception of accountability, I also analyse the effect of formal authority of regional governments. In particular, one might expect the presence of regional governments with strong formal powers to lower citizens' perceptions of government accountability since a highly decentralised system obfuscates the attribution of responsibility. I therefore suggest the following hypothesis:

Hypothesis $6 \mathrm{~b}$. The greater the degree of formal authority of regional governments at the country level, the lower the perceptions of accountability.

Type of welfare state

In the seminal study by Esping-Andersen (1990), welfare states are differentiated according to three elements: decommodification, social stratification and employment. Based on these three elements, the author developed a typology of welfare state regimes in terms of the role that markets, state institutions and families have as mechanisms for the provision well-being: liberal, conservative and social-democratic (or universalistic) models. On the basis of this typology, scholars have since made revisions and added further categories (Arts and Gelissen 2002) which better take into ccount welfare states from the south of Western Europe (the so-called 'southern model' (Ferrera 1996)). In general terms, the objective of welfare states is to guarantee a set of social benefits, such as health or pensions, through different mechanisms (the state, the market or the 
family). With respect to their foundations it is difficult to find a connection that links them with accountability. However, in spite of this, it is worth asking whether it could be expected that certain welfare state models might produce a higher citizen perception regarding how accountable their governments are. According to some scholars, welfare state systems are 'important means for generating public support by influencing individual preferences for extensive social policies' (Koster and Kaminska, 2012: 903-904). Given that the models of welfare regimes differ in the extent of their social benefits, this study aims to investigate whether such differences influence citizens' perceptions with regard to the functioning of government accountability. In particular, I seek to examine whether the universalist model, as the most extensive and generous regime of welfare state, promotes higher citizen valuation of government accountability.

Hypothesis 7. In universalist welfare regimes citizen perception of government accountability is higher than in liberal, conservative, mediterranean and post-communist models.

\section{Data}

The ESS 2012, and specifically its module on democracy, was conducted in 29 countries of which I include 24 countries $(\mathrm{N}=41,933)$ - those where data for the country-level independent variables are available. ${ }^{1}$ As noted, the module on democracy - which includes questions to measure our dependent variable - was only developed in the ESS 2012 wave. This restriction in the data prevents me from analysing different rounds of the survey. Since the countries covered by the ESS have a considerable heterogeneity in their contextual characteristics it would be ideal to examine various institutional and political variables which, according to existing literature, could be relevant for explaining variations in citizen perception of accountability; for example, differences in the level of economic development, in the longevity of democratic regimes, or in the impartiality of government officials. However, the small number of countries prevents the inclusion of many covariates at the country-level. Moreover, since the inclusion of many contextual factors can produce multi-collinearity problems, I examine only three types of contextual variable that existing literature suggests are the most relevant: rule of law, governance structures (single-party governments/authority of regional governments) and the type of welfare state model adopted by countries. As

1 Countries are Belgium, Bulgaria, Cyprus, Czech Republic, Denmark, Estonia, France, Finland, Germany, Hungary, Iceland, Ireland, Italy, Lithuania, Netherlands, Norway, Poland, Portugal, Slovakia, Slovenia, Spain, Sweden, Switzerland, United Kingdom. 
noted above, the remaining independent variables are focused on the individual-level, such as the citizens' perceptions of government performance, as well as their ideological position on the left-right spectrum.

\section{Measurements}

The dependent variable in this study is the individual perception of government accountability. Since the operationalisation of this variable has already been developed above, in the next section I focus on the measurement of the independent variables.

As noted, I used the 2012 ESS wave in order to operationalise the individual-level variables. To test the hypothesis on government performance, I measured satisfaction with the welfare state as well as satisfaction with the state of the economy. Based on Kumlin (2009), I calculated an index of satisfaction with welfare services that averages two questions on the 'state of health services in [country] nowadays' and the 'state of education in [country] nowadays', on a scale from 0 (extremely bad) to 10 (extremely good). With regard to the satisfaction with the state of the economy I employed an index of satisfaction 'with present state of economy in [country]', on a scale from 0 (extremely dissatisfied) to 10 (extremely satisfied). For the ideological position hypothesis, I used the question on placement on the left-right scale: 'In politics people sometimes talk of "left" and "right". Using this card, where would you place yourself on this scale, where 0 means the left and 10 means the right?' Specifically, based on Rodon (2014) I created a categorical variable with four values (left $=0-4$, centre $=5$, right $=6-10$, and $\mathrm{dk} / \mathrm{na}$ in cases where the respondent did not answer). I use the category $\mathrm{dk} /$ na given that left-right self-placement responses have a high level of missing data (15 per cent). To test the hypothesis on ideological proximity, I employed a cross-level interaction between the respondents' ideological position on the left-right scale and the ideological position of the ruling party, which was taken from Chapel Hill expert surveys (CHES) (Bakker et al 2015). In cases of coalition governments I took the ideological position of the political party that was the head of the government coalition during the field work period(s) of the survey for each country. To test the hypothesis on the role of media, I used the question 'in [country] the media provide citizens with reliable information to judge the government' on a scale from 0 (does not apply at all) to 10 (applies completely).

For the contextual-level measures I used the World Bank measure of the rule of law (2011) (see Kaufmann et al 2009). To test the hypotheses on governance structures, I 
identified the presence of ruling government coalitions during the field work period(s) of the survey for each country (single party government $=1$, coalition government $=0)^{2}$ and used the Regional Authority Index 2011, which measures "the extent to which a regional government exercises formal authority" (Hooghe et al 2010: 9). This index analyses two domains: self-rule ("the capacity of a regional government to autonomously exercise authority over those who live in its territory") and share rule ("the capacity to co-determine the exercise of authority for the country as a whole") (Hooghe et al 2010: 11). I focused the analysis on regional self-rule in each country because, as noted above, I am interested in analysing whether the presence of regional governments with strong formal powers over their corresponding territories contributes to increasing the level of citizens' perceptions of government accountability.

Based on the categorisation developed by Esping-Andersen (1990, 1999), I used the following ideal types of welfare regimes: universalist (Denmark, Finland, the Netherlands, Norway and Sweden), conservative (Belgium, France, Germany) and liberal (Switzerland, United Kingdom, Ireland). Since Esping-Andersen's study does not include the case of Iceland, I followed Saint-Arnaud and Bernard (2003) who argue that this country falls into the liberal camp. Based on Ferrera (1996), I also included the southern model (Cyprus, Italy, Spain, Portugal) and, drawing on Castles and Obinger (2008), countries from the so-called post-communist family which are grouped as the post-socialist protection model (Bulgaria, Estonia, Hungary, Lithuania, Slovenia, Slovakia, Czech Republic and Poland). Although this last set of countries does not have consolidated welfare states they can be analysed as transition countries (Ebbinghaus 2012). Some scholars have argued that 'there are some welfare states that stand out in fitting the ideal type most closely, while many others are classified more ambiguously' (Ebbinghaus 2012: 6). In this vein, some studies have suggested that countries such as the Netherlands and Finland have a hybrid character, as their social policies are a product of a mix of models. However, the assignment of these countries to a specific type of welfare state model is based on their principal characteristics. For this purpose, I employed a categorical variable with five values (1=universalist model, $2=$ liberal model, $3=$ conservative model, $4=$ southern model and $5=$ post-communist model).

\footnotetext{
2 I used the data from the Parties and Elections in Europe database. http://www.parties-and-elections.eu/ countries.html
} 
I also included several control variables in the analysis in order to identify whether other individual-level characteristics may have an impact on people's perceptions of accountability. When I analyse the effect of the ideological position of citizens, I control for the ideology of the ruling party (this operationalisation has been discussed above). I also introduced political interest measured on a four-value scale ( $1=$ "Not at all interested', 2= 'Hardly interested', 3='Quite interested', 4= 'Very interested') because previous studies have found that higher levels of political interest are associated with certain citizens attitudes, such as support for political institutions and satisfaction with democracy. Finally, the analysis controlled for some demographic variables, such as age (in years) and educational level (years of schooling), in order to identify whether "cognitive skills" have an impact on perceptions of accountability (Muñoz et al 2011). Based on Muñoz et al (2011), I also controlled for gender ( $1=$ male; $0=$ female) since research on trust in political institutions find that women appear to be more trusting than men. The descriptive statistics for all the variables are presented in Table 3.

[Table 3. Descriptive statistics]

\begin{tabular}{|c|c|c|c|c|}
\hline Variable & Mean & SD & Min. & Max. \\
\hline \multicolumn{5}{|l|}{ Dependent variable } \\
\hline Accountability & 5.27 & 2.52 & 0 & 10 \\
\hline \multicolumn{5}{|l|}{$\begin{array}{l}\text { Individual-level independent } \\
\text { variables }\end{array}$} \\
\hline Public services performance & 5.59 & 2.14 & 0 & 10 \\
\hline Economic performance & 4.14 & 2.60 & 0 & 10 \\
\hline Left-Right ideology- respondent & 2.30 & 1.00 & 1 & 4 \\
\hline Left-Right ideology- government & 5.90 & 1.88 & 1.1 & 9.01 \\
\hline Rol of the media & 6.04 & 2.47 & 0 & 10 \\
\hline \multicolumn{5}{|l|}{ Country-level independent variables } \\
\hline Rule of law & 1.26 & 0.57 & -0.12 & 1.95 \\
\hline Regional Authority Index & 7.79 & 6.26 & 0 & 21.1 \\
\hline Single party government & 0.21 & 0.41 & 0 & 1 \\
\hline Welfare State Model & 3.27 & 1.56 & 1 & 5 \\
\hline \multicolumn{5}{|l|}{ Controls } \\
\hline Political Interest & 2.36 & 0.91 & 1 & 4 \\
\hline Age & 49.47 & 18.55 & 15 & 104 \\
\hline Education & 12.60 & 4.11 & 0 & 51 \\
\hline
\end{tabular}




\begin{tabular}{lccccc}
\hline & Variable & Mean & SD & Min. & Max. \\
\hline Male & 0.46 & 0.50 & 0 & 1 \\
\hline
\end{tabular}

\section{Analysis}

Since the ESS dataset has a multilevel structure I employed a multilevel regression analysis to examine the effect of individual and country level characteristics $(41,933$ individuals nested within 24 countries). Specifically, I use a two-level hierarchical linear model since the dependent variable is a score for accountability ranging from 0 to 10 . Multilevel analysis is adequate when observations are not independent from each other (if the independence assumption is violated standard errors may be biased leading to Type 1 errors) (Heck and Thomas, 2000, Hox 2010). First, I estimated the intercept-only model (not shown) in order to identify the variation at the individual and country levels. The interclass correlation coefficient (ICC) is high 0.21 indicating that $21 \%$ of the variation can be attributed to characteristics between countries. This amount of country level variance demonstrates the need for a multilevel analysis.

Models 1 and 3 include the individual-level covariates. Models 4-8 add the contextual factors. Model 1 estimates satisfaction with welfare state services as an indicator of government performance and incorporates the control variables. Since the level of satisfaction with welfare state services is strongly correlated with satisfaction with the state of the economy (Pearson's r=0.48, p < 0.001), Models 2-8 were conducted using satisfaction with welfare state services as an indicator of government performance. I also run Models 1-8 including satisfaction with the state of the economy as an alternative indicator of government performance (models not show). Model 2 adds respondent ideological position controlling for government ideological position. Model 3 incorporates people's perception of the information provided by the media. Whereas the interclass correlation in the null model is 0.21 , once I include the three individuallevel covariates (in Model 3 ) the interclass correlation is 0.13 , showing that individuallevel characteristics matter in accounting for citizen perception of government accountability. In Models 4-6 I estimate the effect of the contextual-level covariates one at a time. Model 7 includes the two contextual-level covariates that have a significant effect in previous models. Finally, in order to test the hypothesis on ideological proximity, in Model 8 I introduce a cross-level interaction effect of ideological position 
of ruling party (at the country level) and respondents' ideological position. As suggested by the ESS designers, I combine the Design weight and the Population size weight in the analyses. ${ }^{3}$

[Table 4. Citizens' attitudes towards government accountability, Models 1-4]

\begin{tabular}{lcccc}
\hline & Model 1 & Model 2 & Model 3 & Model 4 \\
\hline Individual-level & & & & \\
Public services performance & $0.320^{* * *}$ & $0.313^{* * *}$ & $0.218^{* * *}$ & $0.218^{* * *}$ \\
& $(0.020)$ & $(0.021)$ & $(0.025)$ & $(0.025)$ \\
Left-Right ideology (Left is ref. & & & & \\
cat.) & & & & \\
- Center & & & & \\
& & $(0.063)$ & $(0.057)$ & $(0.057)$ \\
- Right & $0.285^{*}$ & $0.274^{* *}$ & $0.274^{* *}$ \\
& $(0.126)$ & $(0.110)$ & $(0.110)$ \\
- Dk/Na & -0.200 & -0.108 & -0.108 \\
& $(0.129)$ & $(0.082)$ & $(0.082)$ \\
- Rol of the media & & $0.351^{* * *}$ & $0.351^{* * *}$ \\
& & & $(0.025)$ & $(0.025)$ \\
Country-level & & & \\
Rule of law & & & $0.948^{* * *}$ \\
& & & & $(0.280)$
\end{tabular}

Regional Authority Index

Single party gov

Welfare state model ( $\mathrm{sd}$ model is ref. cat.)

Controls

Gov ideology

$\begin{array}{lll}0.120 & 0.090 & 0.029\end{array}$

$\begin{array}{lll}(0.088) & (0.078) \quad(0.060)\end{array}$

Political Interest

$\begin{array}{cccc}0.171 * * * & 0.152 * * * & 0.138 * * * & 0.138 * * * \\ (0.039) & (0.042) & (0.033) & (0.033)\end{array}$

Male (female is ref. cat.)

$0.074 * \quad 0.067 * \quad 0.073 * \quad 0.073 *$

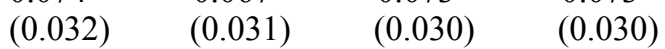

Years of education

$\begin{array}{cccc}-0.015^{* * *} & -0.015 & -0.003 & -0.003 \\ (0.004) & (0.004) & (0.005) & (0.005) \\ 0.011^{* * *} & 0.010^{* * *} & 0.008 * * * & 0.008 * * * \\ (0.002) & (0.001) & (0.002) & (0.002)\end{array}$

Constant

$\begin{array}{cccc}2.664 * * * & 1.995 * * * & 0.576 & -0.248 \\ (0.230) & (0.505) & (0.474) & (0.415)\end{array}$

\footnotetext{
${ }^{3}$ See European Social Survey (ESS) (2010). Weighting European Social Survey Data. http:// www.europeansocialsurvey.org/docs/methodology/ESS_weighting_data.pdf
} 


\begin{tabular}{lcccc}
\hline & Model 1 & Model 2 & Model 3 & Model 4 \\
\hline Variance components & & & & \\
- Group & .89 & 0.81 & 0.61 & 0.33 \\
- Residuals & 4.64 & 4.62 & 3.92 & 3.92 \\
Intraclass corr. (\%) & 0.16 & 0.13 & 0.13 & 0.08 \\
Number of observations & 39,811 & 39,811 & 39,349 & 39,349 \\
\hline
\end{tabular}

Note: Numbers in parentheses represent standard errors. Significant at $* \mathrm{p} \leq .05 ; * * \mathrm{p} \leq .01 ; * * * \mathrm{p} \leq .001$.

[Table 4. Citizens' attitudes towards government accountability, Models 5-8]

\begin{tabular}{lcccc}
\hline & Model 5 & Model 6 & Model 7 & Model 8 \\
\hline Individual-level & & & & \\
Public services performance & $0.219^{* * *}$ & $0.218^{* * *}$ & $0.218^{* * *}$ & $0.216^{* * *}$ \\
& $(0.025)$ & $(0.025)$ & $(0.025)$ & $(0.026)$ \\
Left-Right ideology (Left is ref. & & & & \\
cat.) & & & & \\
- Center & 0.074 & 0.074 & 0.074 & $-0.242^{* *}$ \\
& $(0.057)$ & $(0.057)$ & $(0.057)$ & $(0.084)$ \\
- Right & $0.274^{* *}$ & $0.274 * *$ & $0.274 * *$ & 0.369 \\
& $(0.110)$ & $(0.110)$ & $(0.110)$ & $(0.236)$ \\
- Dk/Na & -0.108 & -0.107 & -0.107 & -0.547 \\
& $(0.082)$ & $(0.082)$ & $(0.082)$ & $(0.294)$ \\
Rol of the media & $0.351^{* * *}$ & $0.351^{* * *}$ & $0.351^{* * *}$ & $0.349 * * *$ \\
& $(0.025)$ & $(0.025)$ & $(0.025)$ & $(0.025)$
\end{tabular}

Country-level

Rule of law

$\begin{array}{cc}0.622 * & 0.940 * * * \\ (0.295) & (0.276)\end{array}$

Regional Authority Index

0.402

$(0.025)$

Single party gov

$-0.213$

(0.323)

Welfare state model (sd model is ref. cat.)

- Liberal

$$
-0.376
$$

- Continental

- Southern 


\begin{tabular}{|c|c|c|c|c|}
\hline & Model 5 & Model 6 & Model 7 & Model 8 \\
\hline - $\mathrm{CEE}$ & & $\begin{array}{l}-1.532 * * * \\
(0.235)\end{array}$ & & \\
\hline $\begin{array}{l}\text { Welfare state model- Dummy } \\
\text { (sd model is ref. cat.) }\end{array}$ & & & $\begin{array}{c}0.753 * * \\
(0.277)\end{array}$ & \\
\hline \multicolumn{5}{|l|}{ Cross-level interaction } \\
\hline \multicolumn{5}{|l|}{$\begin{array}{l}\text { Gov ideology } \\
* \text { Left-Right ideology }\end{array}$} \\
\hline - Center & & & & $\begin{array}{c}0.055^{* *} \\
(0.018)\end{array}$ \\
\hline - Right & & & & $\begin{array}{r}0.112 * * \\
(0.039)\end{array}$ \\
\hline - $\mathrm{Dk} / \mathrm{Na}$ & & & & $\begin{array}{c}0.069 \\
(0.046)\end{array}$ \\
\hline \multicolumn{5}{|l|}{ Controls } \\
\hline Gov ideology & $\begin{array}{c}0.080 \\
(0.076)\end{array}$ & $\begin{array}{c}0.009 \\
(0.045)\end{array}$ & $\begin{array}{c}0.033 \\
(0.057)\end{array}$ & $\begin{array}{l}-0.033 \\
(0.066)\end{array}$ \\
\hline Political Interest & $\begin{array}{l}0.138 * * * \\
(0.033)\end{array}$ & $\begin{array}{l}0.138 * * * \\
(0.033)\end{array}$ & $\begin{array}{c}0.138 * * * \\
(0.033)\end{array}$ & $\begin{array}{c}0.139 * * * \\
(0.034)\end{array}$ \\
\hline Male (female is ref. cat.) & $\begin{array}{l}0.073 * \\
(0.030)\end{array}$ & $\begin{array}{l}0.073 * \\
(0.030)\end{array}$ & $\begin{array}{l}0.073 * \\
(0.030)\end{array}$ & $\begin{array}{l}0.074 * \\
(0.030)\end{array}$ \\
\hline Years of education & $\begin{array}{l}-0.003 \\
(0.005)\end{array}$ & $\begin{array}{l}-0.003 \\
(0.005)\end{array}$ & $\begin{array}{l}-0.003 \\
(0.005)\end{array}$ & $\begin{array}{l}-0.003 \\
(0.005)\end{array}$ \\
\hline Age & $\begin{array}{l}0.008 * * * \\
(0.002)\end{array}$ & $\begin{array}{l}0.008 * * * \\
(0.002)\end{array}$ & $\begin{array}{l}0.008 * * * \\
(0.002)\end{array}$ & $\begin{array}{c}0.008 * * * \\
(0.002)\end{array}$ \\
\hline Constant & $\begin{array}{c}0.375 \\
(0.485)\end{array}$ & $\begin{array}{c}2.06 \\
(0.369)\end{array}$ & $\begin{array}{l}-0.250 \\
(0.453)\end{array}$ & $\begin{array}{c}0.151 \\
(0.459)\end{array}$ \\
\hline \multicolumn{5}{|l|}{ Variance components } \\
\hline - Group & 0.54 & 0.14 & 0.27 & .39 \\
\hline - Residuals & 3.92 & 3.92 & 3.92 & 3.90 \\
\hline - Left-Right ideology & & & & 0.11 \\
\hline Intraclass corr. $(\%)$ & 0.12 & 0.03 & 0.06 & \\
\hline Number of observations & 39,349 & 39,349 & 39,349 & 39,349 \\
\hline
\end{tabular}

Note: Numbers in parentheses represent standard errors. Significant at *p $\leq .05 ; * * \mathrm{p} \leq .01 ; * * \mathrm{p} \leq .001$.

The results in all models confirm that government performance is positively and significantly related to higher perceptions of accountability (all are statistically significant at the .001 level). For example, we observe in Model 1 that if perception of public services performance increases by 1 unit on a scale ranging from 0 to 10 , public 
perception of government accountability increases by 0.320 on a scale from 0 to 10 . As mentioned, I also ran all models including satisfaction with the state of the economy as an alternative indicator of government performance (models not show). The results remain unchanged in terms of the coefficients and statistical significance of the results reported in Table 4. These findings support Hypothesis 1 about government performance, as citizens tend to evaluate government accountability according to the social and economic performance of government. This is in line with the studies by Kayser and Wlezien (2011) and Anderson (1998), who argued that citizens who evaluate national economic performance favourably tend to support government institutions, and also with studies by Kumlin (2009), who found that satisfaction with welfare state services has a positive effect on trust at the national level and the EU level.

Although not all the categories have robust results, the respondents' ideological position appears to produce varied effects on perception of government accountability. The findings show that compared to left supporters right-wing citizens have, on average, a higher perception of government accountability (I checked this result by controlling for the ideology of the ruling party). Specifically, those on the right of the political spectrum score .285 (see Model 2) units higher than the base-line category (left-wing supporters). This result suggests that right-wing respondents tend to express a higher degree of satisfaction with government accountability. In addition, in order to examine the effect of ideological proximity, I ran a cross-level interaction between the respondents' ideological position and the ideological position of the ruling party (see Model 8). The results of the cross-level interaction suggest that the closer respondents are to the ruling party ideologically, the more inclined they will be to find the government accountable. This is in line with the studies of De Vries and Tillman (2011) who argue that greater ideological agreement between the respondent and the ruling party increases respondent support for that government. More interestingly, the results show that right-wing supporters have, on average, a higher perception of government accountability and that they support right-wing governments to a greater extent than left-wing respondents support left-wing governments (see Figure 1).

[Figure 1. Conditional effect of the respondents' ideological position on perception of accountability, by the ideological position of the ruling party] 


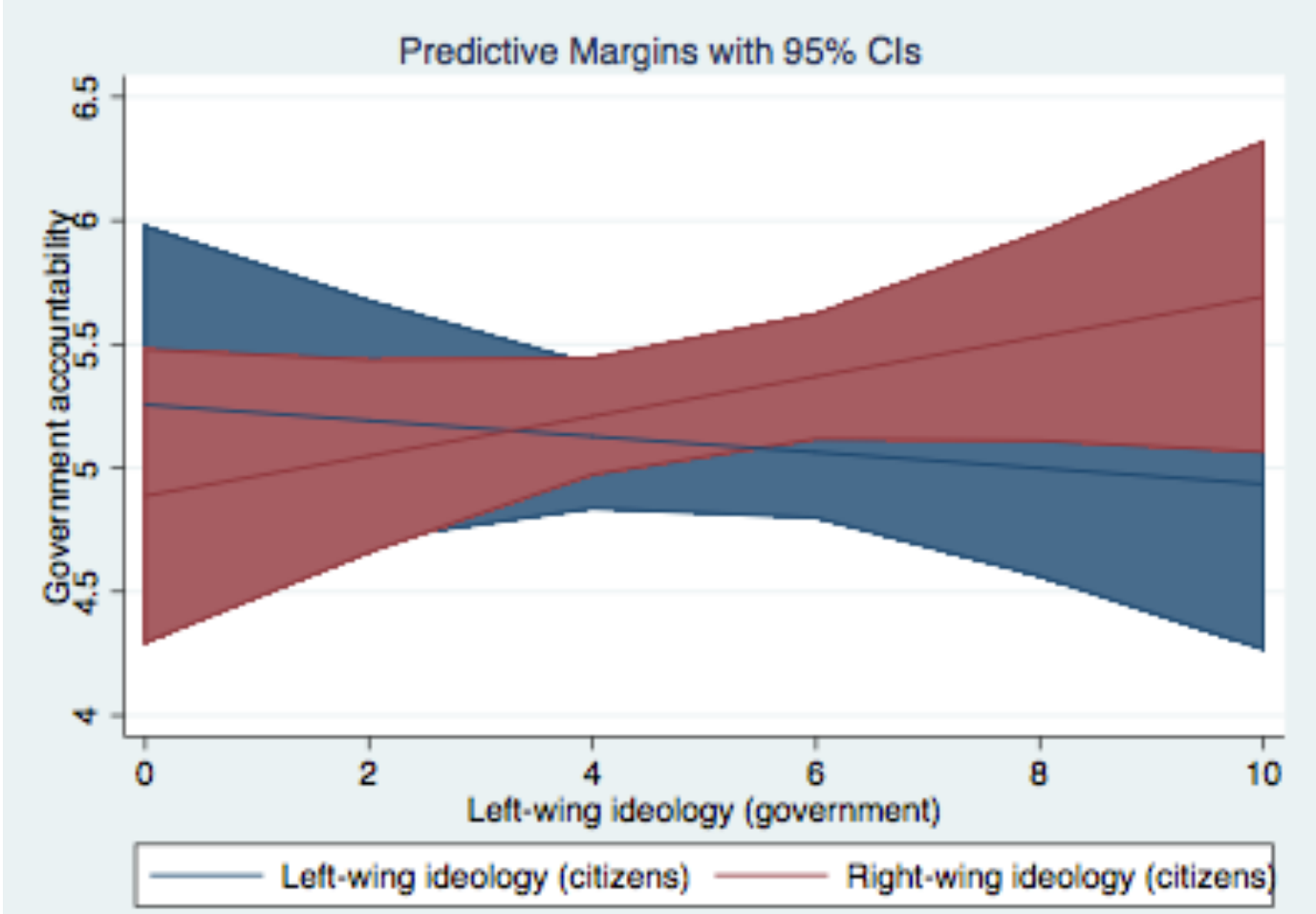

Note: calculations are made on the basis of Model 5.

The findings also support Hypothesis 3 on the role of the media, since citizens respond positively in terms of their perceptions of public accountability when they perceive that the media provides them with reliable information to judge the government. This strong, positive and statistically significant effect is also confirmed by Models 3-8. For 
example, we can observe in Model 3 that if citizen perception of the reliability of information provided by the media increases by 1 unit on a scale ranging from 0 to 10 , public perception of government accountability increases by 0.351 on a scale from 0 to 10. The result is in line with Norris (2014) who argues that independent media help citizens to evaluate their government's performance.

Examining the country-level covariates, the rule of law appears to play an important role on citizens' perception. In particular, we observe that citizens' perceptions of accountability are stronger in countries where the rule of law is well established. For example, Model 4 confirms that rule of law is positively and significantly related to higher perceptions of accountability (statistically significant at the .001 level). Although the governance indicators developed by Kaufman et al (2009) are also based on the perceptions of different actors (such as survey respondents, and public, private and NGO sector experts), it uses a robust set of sources (e.g. around 31 sources in the index 2010) that provide empirical proxies for the de facto existence of the rule of law. In particular, this robust indicator could reflect the extent to which accountability structures are actually present (particularly, mechanisms through which judicial bodies are able to sanction the executive branch). This finding shows that perceptions of accountability are affected by the actual accountability mechanisms to which governments are subject.

As for the two measures of governance structures (regional authority and the presence of coalition governments), the results are not statistically significant. It is important to note that the two survey questions from the ESS that serve as indicators of government accountability do not specify whether these refer to a particular level of government, meaning that further research across central and regional governments is needed to examine the effect of governance structures on government accountability.

In line with Hypothesis 6, coefficients for type of welfare state suggest that perception of accountability is higher in our category of reference - the universalist or socialdemocratic type of welfare state - and much lower in the southern, conservative and post-communist models. If we take as a base category the social-democratic model of welfare state, negative coefficients are observed in all other models. For example, citizens that live in the southern type of welfare regime score 1.87 units lower than those living a social-democratic model (see Model 6). However, it is important to note that the coefficients for the liberal model of welfare state are not statistically significant, which could be due to the fact that, in general, levels of accountability do not have 
substantial differences between both models of welfare state. This finding supports the initial hypothesis, which suggested that citizens would have a higher perception of government accountability in countries where the welfare state was more generous and characterised by a higher degree of decommodification. That is to say, higher perceptions of accountability would be expected where the state was the main provider of welfare services. The types of welfare states that have a negative relationship with perceived accountability are the conservative model and the southern model, which are characterised by moderate levels of decommodification. A possible interpretation regarding the conservative and southern regimes, which requires further analysis, suggests that in countries where the family is one of the main providers of welfare, the connection between the government and citizens is weakened. As for the case of postcommunist countries, the results suggest that in countries where the welfare regime is not consolidated the relationship between citizens and their governments is also weak. As a robustness check for this finding, I also ran the analysis including a dichotomous variable expressing whether the type of welfare state is social-democratic $(v=1)$, or not $(v=0)$ (not shown). The coefficients and statistical significance of the results remain unchanged. For example, citizens that live in a social-democratic welfare regime score 1.26 units higher than those living in a different type of welfare regime (statistically significant at the .001 level).

As a robustness check I ran the analysis including the two contextual covariates that in previous models had been shown to be significant. The effect of the rule of law disappeared once the typology of welfare state was included (not reported here). This suggests that we cannot distinguish the effect of the type of welfare state from the effect of the rule of law on citizen perception of accountability owing to multicollinearity; both covariates are strongly correlated (Pearson's $\mathrm{r}=.88, \mathrm{p}<0.001$ ). In order to tackle this, I also ran the analysis (Model 7) using a dummy variable expressing whether the type of welfare state is social-democratic $(v=1)$ or not $(v=0)$ (Pearson's $r=0.57, p<$ 0.001). Although the correlation between the rule of law and type of welfare regime is high, the results show statistical evidence that both variables affect citizens' perceptions of government accountability. A future line of research could examine the effect of other variables since it is possible to expect that the type of welfare state could be mediated by the effect of other contextual variables. For example, the type of welfare regime is relevant as it reflects institutional traditions, which differ in their social policy design (for example, social policies that differ in terms of the role that the state or the market have as providers of well-being) but also in terms of the institutional rules (e.g. administrative traditions) within which both governments and citizens operate. 
Finally, although the effect is very weak, the analysis reveals that almost all of the controls, education being the exception, are significant, indicating that age, gender and political interest are positively related to higher perceptions of accountability. These results show that younger respondents appear to be less trusting of government accountability. Moreover, although previous research (Muñoz et al 2011) has shown that females tend to be more supportive of public institutions, the findings here suggest that female citizens tend to be more critical with respect to accountability. In addition, contrary to our expectations, years of education do not appear to have any effect on attitudes towards accountability. As expected, citizens' level of political engagement has a positive effect on accountability. This finding suggests that more attentive and active citizens have more positive attitudes regarding public accountability.

\section{Conclusion}

The aim of this study was to contribute to the scholarship on public accountability through an analysis of the largest receiving forum in representative democracies: the citizens. Citizens' perceptions can serve as a 'thermostat function' that enable us to understand how successfully the mechanisms put in place to inform, justify, evaluate and sanction the decisions and actions of governments reach into the attitudes of the general population.

This study has shown that both contextual-level variables and individual-level variables are relevant for explaining citizens' attitudes regarding government accountability. At individual level, the study showed that citizens who favourably evaluate the government performance, those who consider the media to provide them with reliable information by which to judge governments, and those who are located on the right-wing of the political spectrum are more likely to positively evaluate government accountability. Looking across levels, the study found evidence that greater ideological affinity between the respondents and the ruling party increases the respondents' support for that government, particularly, that right-wing respondents support right-wing governments to a greater extent than left-wing respondents support left-wing governments. 
At the country level, the study demonstrated that citizens' evaluations of accountability are more positive in countries with well-established rule of law, which confirms that perceptions of accountability are affected by the actual accountability mechanism to which the governments are subject. Also at the country level, the analysis showed that positive assessments of accountability are more likely in countries with more extensive and generous welfare states, particularly in social-democratic regimes, where the state is the main provider of welfare services.

It is important to highlight that this study did not assess formal accountability or de facto governmental accountability; a more extensive investigation would allow us to delve into the relationship between, on the one hand, the accountability mechanisms that develop through formal regulation and governmental action, and, on the other, those that citizens ultimately perceive.

\section{References}

Anderson Christopher J. (1998). 'When in Doubt, Use Proxies: Attitudes Toward Domestic Politics and Support for European Integration', Comparative Political Studies, 31, 569-601.

Anderson, Christopher J. and Matthew M. Singer (2008). 'The Sensitive Left and the Impervious Right: Multilevel Models and the Politics of Inequality, Ideology, and Legitimacy in Europe', Comparative Political Studies, 41:4-5, 564-99.

Arnold, Douglas R. (2004). Congress, the Press, and Political Accountability. Princeton: Princeton University Press.

Arts, Will and John Gelissen (2002). 'Three worlds of welfare capitalism or more? A state-of-the-art report', Journal of European Social Policy, 12:2,137-58.

Bakker Ryan, Catherine E. De Vries, Erica Edwards, Liesbet Hooghe, Seth Jolly, Gary Marks, Jonathan Polk, Jan Rovny, Marco Steenbergen, Milada Anna Vachudova (2015). 'Measuring party positions in Europe: The Chapel Hill expert survey trend file, 1999-2010', Party Politics, 21:1, 143-52.

Biela, Jan and Yannis Papadopoulos (2014). 'The Empirical Assessment of Agency Accountability: A Regime Approach and an Application to the German Bundesnetzagentur', International Review of Administrative Sciences, 80:2, 36281.

Bovens, Mark (2007). 'Analysing and assessing accountability. A Conceptual Framework', European Law Journal, 13:4, 447-68.

Bovens, Mark (2010). 'Two Concepts of Accountability: Accountability as a Virtue and as a Mechanism', West European Politics, 33:5, 946-67. 
Busuioc, Madalina (2013). European Agencies: Law and Practices of Accountability, Oxford: University Press.

Brandsma, Gijs J. and Thomas Schillemans (2013).'The Accountability Cube: Measuring Accountability', Journal for Public Administration Research and Theory, 23:4, 953-75.

Castles, Francis G. and Herbert Obinger (2008). 'Worlds, Families, Regimes: Country Clusters in European and OECD Area Public Policy', West European Politics, 31:1-2, 321-44.

Chaqués-Bonafont Laura and Anna M. Palau (2011). 'Assessing the Responsiveness of Spanish Policymakers to the Priorities of their Citizens', West European Politics, 34:4, 706-30.

Dahlberg, Stefan and Sören Holmberg (2013). 'Democracy and Bureaucracy: How Their Quality Matters for Popular Satisfaction', West European Politics, 37:3, 515-37.

De Vries Catherine E. and Erik R. Tillman (2011). 'European Union issue voting in East and West Europe: The role of political context', Comparative European Politics 9(1): 1-17.

Devos, Thierry, Dario Spini and Shalom H. Schwartz (2002). 'Conflicts among human values and trust in institutions', British Journal of Social Psychology, 41, 481-94.

Dubnick, Melvin J. and George H. Frederickson (2009). 'Accountable Agents: Federal Performance Measurement and Third-Party Government', Journal of Public Administration Research and Theory, 20(suppl 1): i143-i159.

Ebbinghaus, Bernhard (2012). 'Comparing Welfare State Regimes : Are Typologies an Ideal or Realistic Strategy?', Paper presented at European Social Policy Analysis Network, ESPAnet Conference, Edinburgh, UK, September 6- 8.

Esping-Andersen, Gøsta (1990). Three Worlds of Welfare Capitalism. Cambridge: Polity Press.

Esping-Andersen, Gøsta (1999). Social Foundations of Postindustrial Economies. Oxford: Oxford University Press.

Ferrera, Maurizio (1996). 'The "Southern” Model of Welfare in Social Europe', Journal of European Social Policy, 6:1, 17-37.

Fisher, Stephen D. and Sara Hobolt (2010). 'Coalition Government and Electoral Accountability', Electoral Studies, 29:3, 358-69.

Grant, Ruth W. and Robert O. Keohane (2005). 'Accountability and abuses of power in world politics', American Political Science Review, 99:1, 29-43.

Gregory Robert (2003). 'Accountability in modern government', in G.B. Peters and J. Pierre (eds.), Handbook of Public Administration, London: Sage Publications.

Hanretty, Chris and Christel Koop (2013). 'Shall the law set them free? The formal and actual independence of regulatory agencies', Regulation \& Governance, 7:2, 195-214.

Hood, Christopher (2010). 'Accountability and Transparency: Siamese Twins, Matching Parts, Awkward Couple?', West European Politics, 33:5, 989-1009.

Hooghe Marc and Anna Kern (2013. 'Party membership and closeness and the development of trust in political institutions. An analysis of the European Social Survey, 2002-2010', Party Politics (OnlineFirst).

Hooghe Liesbet, Gary Marks and Arjan H. Schakel (2010). The Rise of Regional Authority: A Comparative Study of 42 Democracies. London: Routledge. 
Hox, Joop J. (2010). Multilevel Analysis, Techniques and Applications. New York: Routledge.

Heck, Ronald H. and Scott L. Thomas (2000). An Introduction to Multilevel Modelling Techniques. Mahwah, NJ: Laurence Erlbaum Associates.

Kaufmann, Daniel, Aart Kraay, and Massimo Mastruzzi (2009). Governance Matters VIII: Aggregate and Individual Governance Indicators 1996-2008. World Bank Policy Research Working Paper Series, No. 4978. World Bank, Washington, DC.

Kayser, Mark A. and Christopher Wlezien (2011). 'Performance Pressure: Patterns of Partisanship and the Economic Vote', European Journal of Political Research, $50: 3,365-94$.

Koop, Christel (2011). 'Explaining the accountability of independent agencies: The importance of political salience', Journal Public Policy, 31:2, 209-34.

Koop, Christel (2014). 'Theorizing and Explaining Voluntary Accountability', Public Administration, 9:3, 565-81.

Koster, Ferry and Monika-Ewa Kaminska (2012). 'Welfare state values in the European Union, 2002-2008. A multilevel investigation of formal institutions and individual attitudes', Journal of European Public Policy, 19:6, 900-20.

Kumlin, Staffan (2009). 'Blaming Europe? Exploring the Variable Impact of National Public Service Dissatisfaction on EU Trust', Journal of European Social Policy, 19:5, 408-20.

León, Sandra (2011). 'Who is responsible for what? Clarity of responsibilities in multilevel states: The case of Spain', European Journal of Political Research, 50:1, 80-109.

Lindberg, Staffan I. (2013). 'Mapping Accountability: Core Concept and Subtypes', International Review of Administrative Sciences, 79:2, 202-26.

Lord, Christopher and Johannes Pollak (2010). 'Representation and Accountability: Communicating Tubes?', West European Politics, 33:5, 968-88.

Maggetti, Martino (2012). The Media Accountability of Independent Regulatory Agencies. European Political Science Review, 4:3, 385-408.

Moncagatta, Paolo (2012). Towards a better comprehension of satisfaction with democracy, RECSM Working Paper 27.

Mulgan, Richard (2000). “'Accountability": An Ever-Expanding Concept?', Public Administration, 78:3, 555-73.

Muñoz, Jordi, Mariano Torcal and Eduard Bonet (2011). 'Institutional trust and multilevel government in the European Union', European Union Politics, 12:4, 551-74.

Norris, Pippa (2014). 'Watchdog Journalism', in M. Bovens, R.E. Goodin and T. Schillemans (eds.), The Oxford Handbook of Public Accountability. Oxford: Oxford University Press. pp. 525-41.

North, Douglass C. (1990) Institutions, Institutional Change, and Economic Performance. Cambridge: Cambridge University Press.

O’Donnell, Guillermo (1998). 'Horizontal accountability in new democracies', Journal of Democracy, 9:3, 112-26.

Olsen, Johan P. (2013). 'The Institutional Basis of Democratic Accountability', West European Politics, 36:3, 447-73.

Page, Edward C. (2010). 'Accountability as a Bureaucratic Minefield: Lessons from a Comparative Study', West European Politics, 33:5, 1010-29. 
Papadopoulos, Yannis 2010). 'Accountability and Multi-level Governance: More Accountability, Less Democracy?', West European Politics, 33:5, 1030-49.

Pérez Durán, Ixchel (2015) 'Assessing formal accountability for public policies: the case of health policy in Spain', International Review of Administrative Sciences, doi: $10.1177 / 0020852314565999$.

Philp, Mark (2009). 'Delimiting Democratic Accountability', Political Studies, 57:1, $28-53$.

Powell, Bingham G. and Guy D. Whitten (1993). 'A cross-national analysis of economic voting: taking account of the political context', American Journal of Political Science, 37:2, 391-414.

Przeworski, Adam, Susan C. Stokes and Bernard Manin (eds.) (1999). Democracy, Accountability and Representation. Cambridge, UK: Cambridge University Press.

Rodríguez Daniel B, Mathew D. McCubbins and Barry R. Weingast (2010). 'The Rule of Law Unplugged', Emory Law Journal, 59:6,1455-494.

Rodon, Toni (2014). 'Do All Roads Lead to the Center ? The Unresolved Dilemma of Centrist Self-Placement', International Journal of Public Opinion Research, First published online.

Romzek, Barbara S. and Melvin J. Dubnick (1998). 'Accountability', in J.M. Shafritz (ed.), International Encyclopedia of Public Policy and Administration, Vol. 1: AC, Boulder, CO: Westview Press.

Saint-Arnaud, Sébastien and Paul Bernard (2003). 'Convergence or Resilience? A Hierarchical Cluster Analysis of the Welfare Regimes in Advanced Countries', Current Sociology, 51:5, 499-527.

Schillemans, Thomas (2008). 'Accountability in the Shadow of Hierarchy: The Horizontal Accountability of Agencies', Public Organization Review, 8:2, 17594.

Schillemans, Thomas (2012). Mediatization of Public Services. How Public Organizations Adapt to News Media. Frankfurt: Peter Lang.

Schillemans, Thomas and Sandra H.J. Jacobs (2014). 'Between a Rock and a Hard Place: Framing Public Organizations in the News', in J. Pallas, L. Strannegård and S. Jonsson (eds.), Organizations and the Media Organizing in a Mediatized World. New York: Routledge.

Strøm, Kaare (2000). 'Delegation and Accountability in Parliamentary Democracies', European Journal of Political Research, 37:3, 261-89.

Vowles, Jack (2010). 'Making a Difference? Public Perceptions of Coalition, SingleParty, and Minority Governments', Electoral Studies, 29:3, 370-80.

Wlezien, Christopher and Stuart N. Soroka (2012).'Political Institutions and the Opinion-Policy Link', West European Politics, 35:6, 1407-432. 